\title{
HYDROTHERMAL ALTERATION ZONES DETECTION IN LIMNOS ISLAND, THROUGH THE APPLICATION OF REMOTE SENSING
}

\author{
Anifadi A. ${ }^{1}$, Parcharidis Is. ${ }^{1}$ and Sykioti O. ${ }^{2}$ \\ ${ }^{1}$ Harokopeio University of Athens, Department of Geography, El. Venizelou 70, 176 71, Athens, \\ Greece,parchar@hua.gr,alexandra.tragana@gmail.com \\ ${ }^{2}$ Institute for Astronomy, Astrophysics, Space Applications \& Remote Sensing Vas. Pavlou \& I. \\ Metaxa, GR-15 236 Penteli, Greece, sykioti@noa.gr
}

\begin{abstract}
In this study we use Landsat 8 OLI satellite imagery in order to identify and map alteration zones in Limnos island (N. Aegean, Greece). Pre-processing included sea and vegetation masking. In order to enhance spatial resolution, data fusion to $15 \mathrm{~m}$ is performed. A lineament map is extracted from the panchromatic image that gives the general tectonic view of the island. The detection and mapping of alteration minerals is performed using specific band ratios and consequent composite images. The colour composite using bands 10,11, $7(R G B)$ show the spectral signature and general distribution of silica. Band ratios $6 / 7,4 / 2,6 / 5$, reveal alteration zones containing iron oxides, clay alteration and ferrous minerals correspondingly. The aforementioned analysis has shown that hydrothermally alteration areas in Limnos are located in the west part of the island and at the Fakos Peninsula, Sardes, Roussopouli and Paradeisi hill. These areas are compared and validated with the reported field work. We conclude that hydrothermal alteration zones can indeed be detected and mapped using medium resolution satellite multispectral data. However, for the identification and mapping of specific types of rocks and minerals, a sensor with high spectral resolution is required.
\end{abstract}

Keywords: Satellite data, Landsat 8 OLI, Miocene Volcanism.

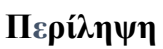

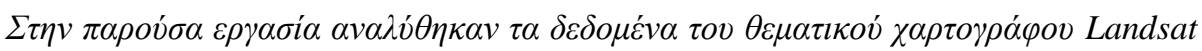

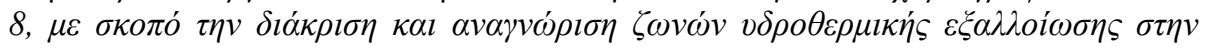

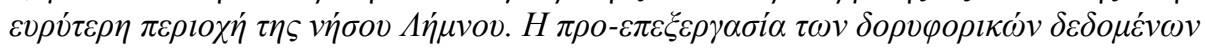

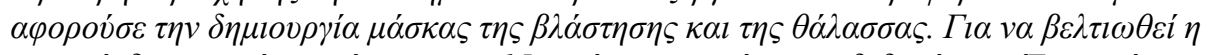

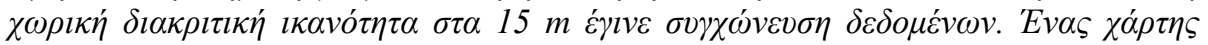

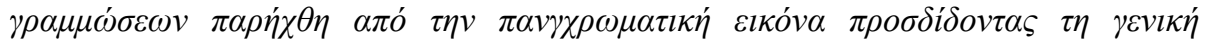

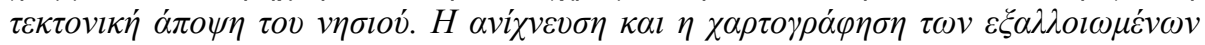

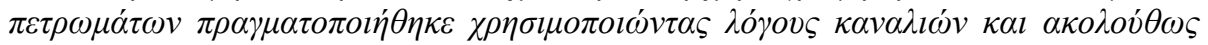

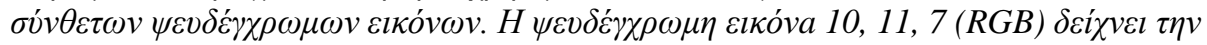

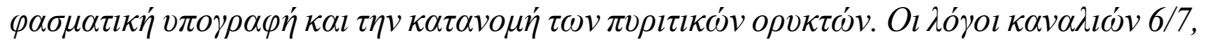

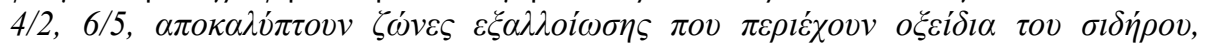

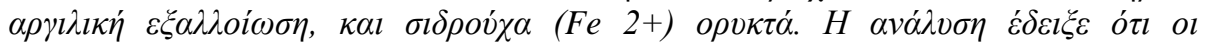

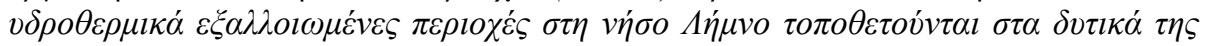

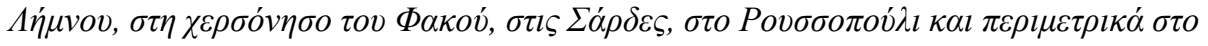




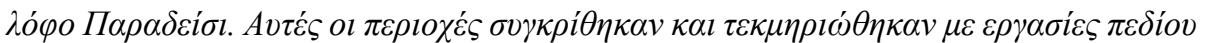

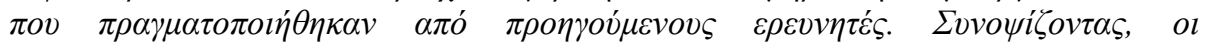

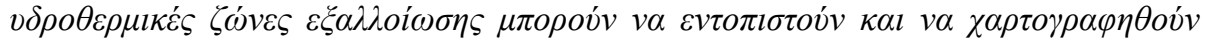

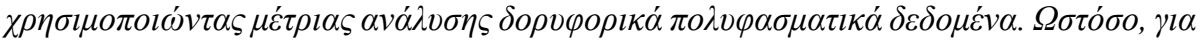

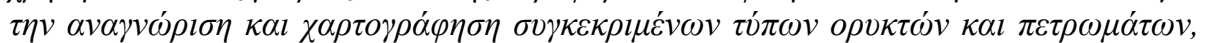

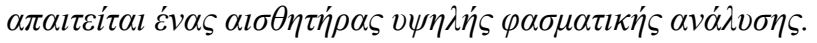

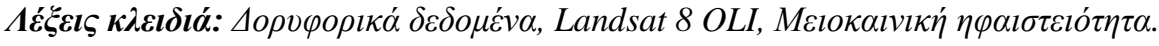

\section{Introduction}

The goal of the present paper is to detect the hydrothermal alteration zones in Limnos Island, N. Aegean, through the application of Landsat 8 OLI band ratios. The key elements in mineral exploration are to gain understanding of geologic area through lithological mapping and to assist in defining target areas of potential mineral interest. Remote sensing can assist and provide valuable information in bedrock mapping, detection, identification and estimating affluence of specific minerals at a specific scale (Ahmed and Beiranvand Pour, 2014; Sabins, 1999; Parcharidis et al., 1998; Hunt, 1977). In Limnos Island, field geological studies have referred the detection of hydrothermal alteration zones in several sites like Sardes, Roussopouli and Fakos peninsula (Papoulis et al., 2014; Fornadel, 2010; Papoulis et al., 2009; Skarpelis and Voudouris, 1998). Positive results can be obtained using band rationing and false colour using these ratios. Limnos island is located at the North Aegean sea in Greece. The island occupies $476 \mathrm{Km}^{2}$ with a coastal line of $260 \mathrm{Km}$. To sum up the hydrothermal alteration zones can indeed be detected and mapped using medium resolution satellite multispectral data but it is not possible to identify and map specific types of rocks and minerals.

\section{Geologic Settings}

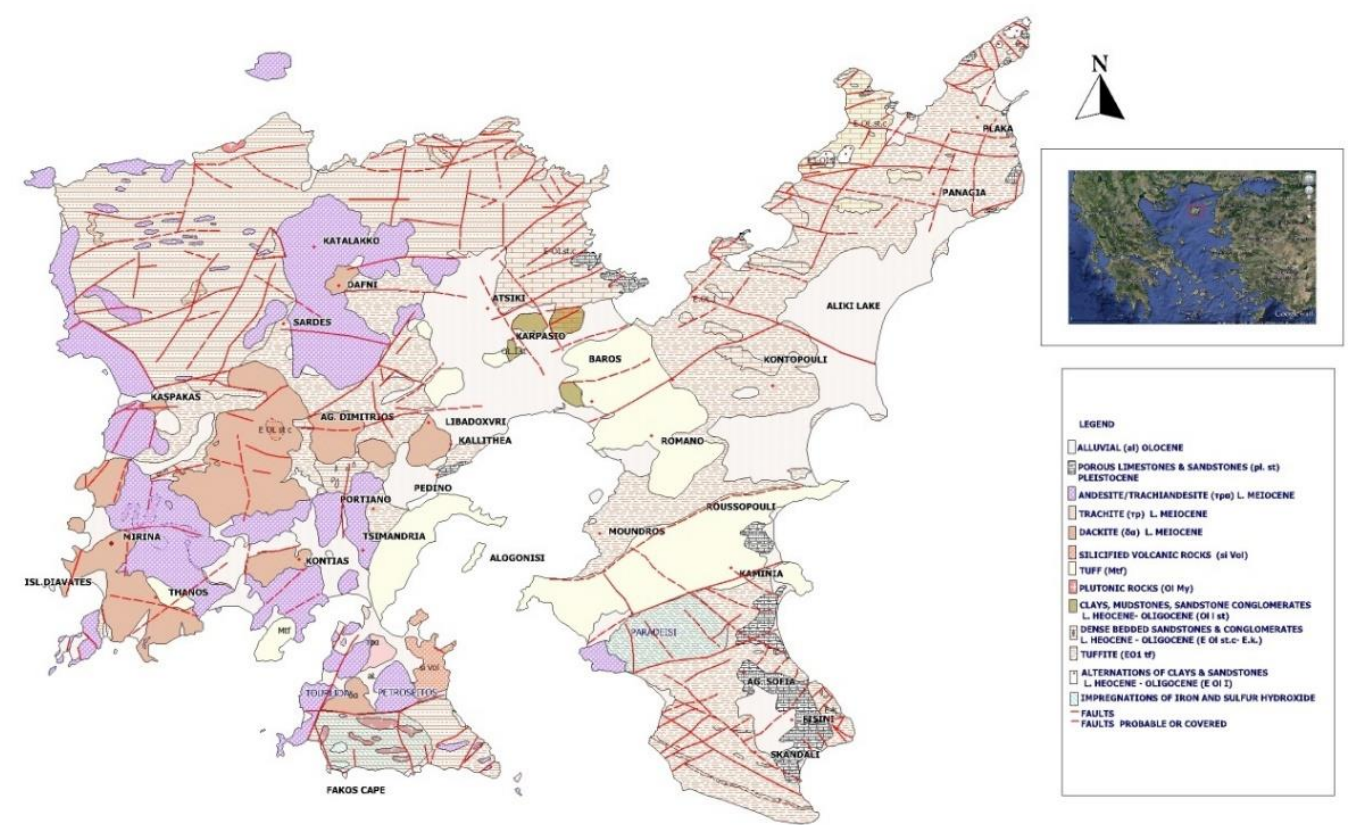

Figure 1 - Digitized geologic map of Limnos island (after IGME scale 1:50000). 


\subsection{Stratigraphy}

Limnos is an island of Greece in the northern part of the Aegean Sea. The principal town of the island and seat of the municipality is Myrina. The island is mostly flat (hence its more than 30 sand beaches), but the west, and especially the northwest part, is rough and mountainous. The main gulfs are Moundros and Pournia, but the rock weathering creates many coves. The areas with high frequency, a dense hydrographical system and big slope use to be faults with direction NW-SE, NE-SW. Generally, at the center and east of the island the rocks are permeable (Quaternary) so the hydrographical system is poor. On the other hand, at the rest of the island the hydrographical system is dense (volcano rocks).

\subsection{Geology}

The geology of Limnos Island is characterized by a sedimentary background which is a basin-fill succession. Hydrothermal alteration in the island is linked to early Miocene volcanism that occurred in the broader north-eastern Aegean Sea and Western Turkey. The remnants of large stratovolcanoes are present in specific areas in the islands of Lesvos, Limnos and Samothraki and in western Turkey. The sedimentary rocks are flysch and molasse. They were deposited in NE-SW trending postorogenic basin that formed as a result of normal faulting and extension during postorogenic collapse of the Rhodope-Sakarya zone and were slightly folded prior to igneous activity. The Tertiary sedimentary basement rocks can be delineated into two discrete units, the Upper Unit and the Lower Unit. The Upper Eocene to lower Oligocene Lower Unit covers the majority of the island and is composed of siliclastic continental slope deposits including conglomerates, sandstones, mudstones, claystones and turbidites. The lower Oligocene Upper Unit has been deposited in a shallower environment than the Lower Unit. Lower in its section, the Upper Unit is composed of marine and brackish fluviodeltaic sediments including interbedded claystones and sandstones, sandstones and sandy limestones. Towards the top of its exposure, the Upper Unit is composed of terrestrial fluvial sediments including conglomerates and sandstones. The volcanic centers are located in the western and southwestern portions of the island where volcanic rocks overlie the sedimentary basement. The presence of the volcanic centers is delineated by domes and lava flows that are accompanied by lesser agglomerate. The sedimentary basement is exposed at the surface in the east and northeast of the island, distal to the volcanic centers. The volcanic rocks are divided into three units: Katakolon, Romanou and Myrina. These rocks are early Miocene (21-18 Ma) and demonstrate a calc-alkaline to shoshonitic affinity. The lower-most Katakolon unit consists of NWSE trending K-rich andesitic to dacitic lavas. In places, it is interbedded with or is crosscut by andesitic lava flows monomineralic breccias, sills and E-W trending dikes. Andesite and dacite in the Katakolon unit yielded a K-Ar age of 20-21 Ma. The Katakolon unit is overlain by the Romanou unit that is composed of K-rich dacites and latites. At its base, the Romanou unit is dominated by ligh- colored lithic and pumice-rich pyroclastic flows that are up to $160 \mathrm{~m}$ thick. To the west and upsection, the pyroclastic flows of the Romanou unit are intercalated with volcanic breccias, banakitic lavas, airfall tuffs and terrigenous sediments. Ignimbrites and andesites from the Romanou unit yielded K-Ar ages of 19.8 Ma. The uppermost Myrina unit, overlies Romanou unit and is composed of K-rich dacite with lesser amounts of andesite and trachyte, which are associates with monomineralic breccias, lava lows, and lahars. Lavas, dackites and andesites of the Myrina unit yielded K-Ar ages of 19.3 to 18.2 Ma. Both volcanic and sedimentary basements of Limnos Island are overlain by a Pliocene to recent alluvial sedimentary unit that is composed of conglomerates, calc-arenites and sandstones. Faults and joints cut-cross both sedimentary and igneous rocks. The axes trend E-W and WSW-ENE to the WSW. Folding does not affect the Miocene volcanic rocks. Limnos Island is located in the area of Aegean Sea that is characterized by a moderate positive heat flow anomaly. This anomaly, in conjunction with active hot springs found on the island, indicate that a steepened thermal gradient has persisted even after the end of observable igneous activity on the island (Skarpelis and Voudouris, 1998; Fornadel, 2010). The presence of hot springs on the island implies that brittle structures on the island play a role in conducting fluids (Fornadel, 2010). 


\subsection{Metal bearing}

The area of Fakos peninsula is dominated by two large hills, the western Tourlida Hill and the Petrospitos Hill both of which are $300 \mathrm{~m}$ in elevation. Their prominence is controlled by subvolcanic intrusions that were emplaced into the sedimentary host rocks. The sedimentary basement on Fakos peninsula is composed largely of medium-grained quartz - rich sandstones that were subjected to, and cemented by a hydrothermal silicification event. Finely disseminated sulfides are pervasive in these sandstones. The extrusive rocks on Fakos Peninsula range from shoshonitic andesites (latites) to trachyandesites and trachytes. Towards the central portion of Fakos peninsula, the extrusive sedimentary basement rocks were intruded by subvolcanic microporphyritic quartz monzonite. Much of the southwestern portion of Limnos Island was subject to hydrothermal alteration along fault zones. Four discrete zones of hydrothermal alteration based on clay mineralogy were defined as smectite, illite, hallousite and kaolinite-dickite zones. The Fakos Peninsula like the rest of Limnos island is crosscut by many major NE-SW and ENE-WSW-trending faults. These structures controlled the emplacement of the subvolcanic bodies and facilitated the flow of hydrothermal -magmatic fluids that were responsible for metallic mineralization. Fakos quartz monzonite and adjacent host rocks were locally subjected to intense hydrothermal alteration. In silica zones there is a metal bearing, to the south of the area and especially to the quartz veins within the sandstones and to the quartz monzonite. At the western metal bearing zone in the quartz veins with direction $\mathrm{N} 55^{\circ} \mathrm{W} \kappa \alpha \mathrm{N} 70^{\circ} \mathrm{E}$. The east metal bearing zone, large $1 \mathrm{Km}$ and wide $10 \mathrm{~m}$, is located about $600 \mathrm{~m} \mathrm{SE}$ of the central zone and it is characterized by the major concentration of gold of the Fakos Peninsula. In the Sardes area, a system of quartz is developed inside the subvolcanic and sandstones and is connected with faults systems of direction $\mathrm{N} 55^{\circ} \mathrm{W}, \mathrm{N} 70^{\circ} \mathrm{A}$ (like in Fakos area). In the Roussopouli area: three zones of black silification are observed in the volcanic breccias. The silification is opaline and is connected with sericitic alteration of the adjacent rock. The zone of alunite is developed up from the silicification zone. The metal-bearing includes pyrite, marcasite and veinlets of silica (Voudouris and Skarpelis, 1998).

\section{Materials and Methods}

\subsection{Remote sensing data}

Landsat 8 is the new product from NASA under Landsat open source series which has been launched in February 2013. Landsat 8 data consist of 11 bands; 5 in the visible and Near-Infrared (VNIR), 2 in the Thermal Infrared (TIR) region of the electromagnetic spectrum, 2 in the Shortwave Infrared (SWIR) region, and 1 panchromatic band (band 8). The spatial resolution is $15 \mathrm{~m}$ for the panchromatic band, $30 \mathrm{~m}$ for VNIR and SWIR bands, and $100 \mathrm{~m}$ for the TIR bands. Two additional bands represent the difference between Landsat8 and the previous product (Landsat ETM+), a deep blue coastal / aerosol band and a shortwave-infrared cirrus band (table 1).

Table 1 - Bands of Landsat 8.

\begin{tabular}{|l|c|c|}
\hline \multicolumn{1}{|c|}{ BAND } & $\begin{array}{c}\text { WAVELENGHT } \\
\text { (micrometers) }\end{array}$ & $\begin{array}{c}\text { RESOLUTION } \\
\text { (meters) }\end{array}$ \\
\hline Band 1 - Coastal aerosol & $0.43-0.45$ & 30 \\
\hline Band 2 - Blue & $0.45-0.51$ & 30 \\
\hline Band 3 - Green & $0.53-0.59$ & 30 \\
\hline Band 4 - Red & $0.64-0.67$ & 30 \\
\hline Band 5 - Near Infrared (NIR) & $0.85-0.88$ & 30 \\
\hline Band 6 - SWIR 1 & $1.57-1.65$ & 30 \\
\hline Band 7 - SWIR 2 & $2.11-2.29$ & 30 \\
\hline Band 8 - Panchromatic & $0.50-0.68$ & 15 \\
\hline Band 9 - Cirrus & $1.36-1.38$ & 30 \\
\hline Band 10 - Thermal Infrared (TIRS) 1 & $10.60-11.19$ & 100 \\
\hline Band 11 - Thermal Infrared (TIRS) 2 & $11.50-12.51$ & 100 \\
\hline
\end{tabular}


The Landsat 8 Oli image which has been used in this study cloud free acquired on August 162014. The sun azimuth is about $\mathrm{B} 139^{\circ}$ and the sun elevation about $57^{\circ}$.

\subsection{Image processing}

The initial DN values were converted to reflectance through atmospheric correction of the initial image. In Fig. 1 a flowchart showing with the processing steps is presented. The following four images were then produced. A colour composite image with the spectral bands 7, 5, 3 (RGB) in order to distinguish the lithological units from the vegetation (Fig. 2).

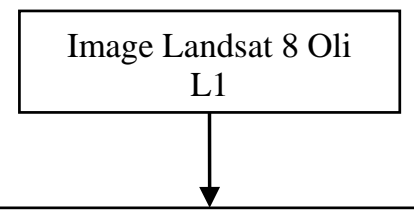

pre-processing of the image: converting the digital numbers of the image to reflectance through atmospheric correction of the initial image.

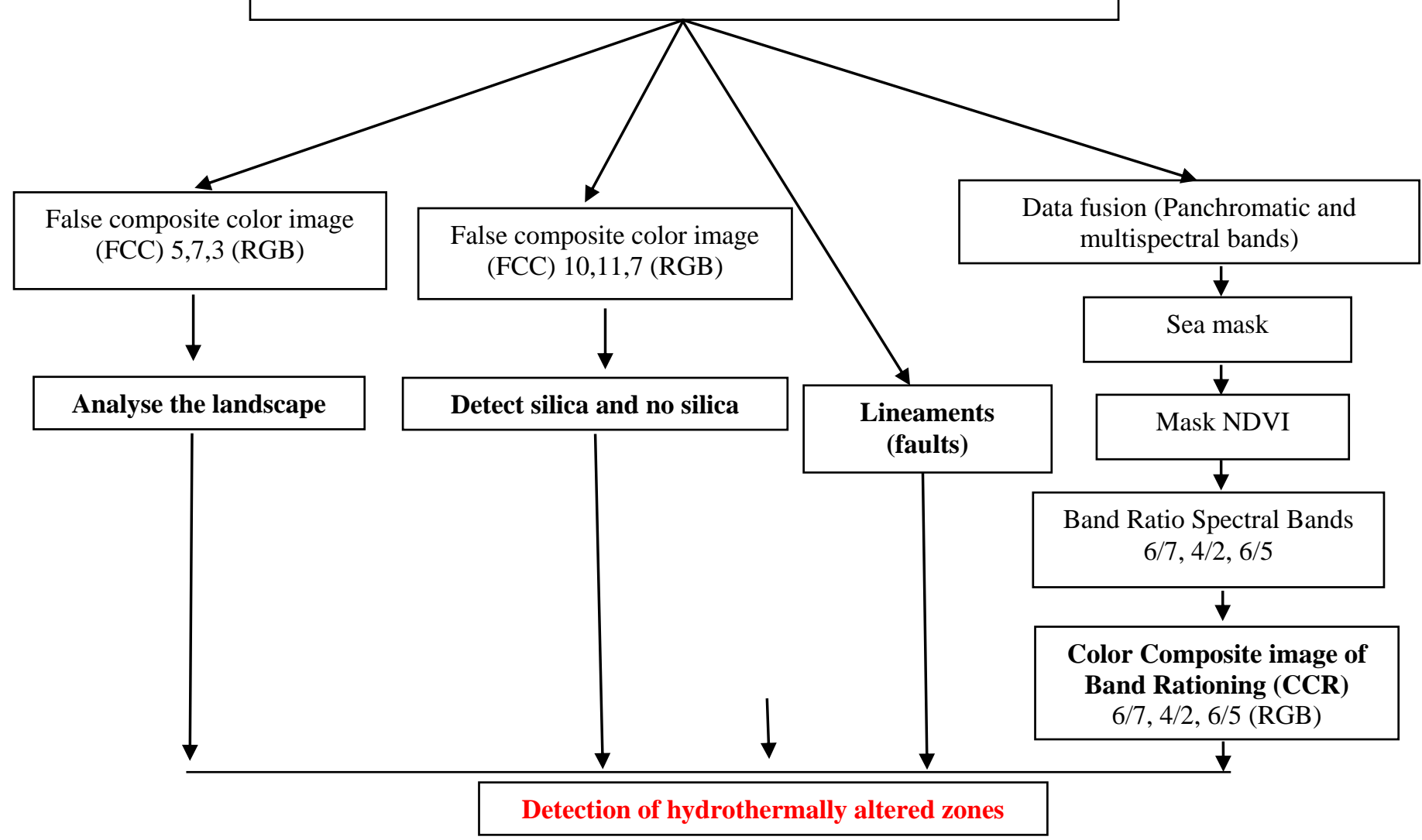

Figure - Flow chart: processing steps.

The Normalized Difference Vegetation Index (NDVI) in order to discern the vegetation distribution and consequently mask of vegetated areas. A colour composite image using the thermal bands tir1tir2-swir2 (10-11-7) (RGB) for silicate mapping (Fig.3).

The colour composite ratio image $6 / 7,4 / 2,6 / 5$ (RGB). The ratio $6 / 7$ reveals clays, the $4 / 2$ iron oxides and the $6 / 5$ the ferrous $(\mathrm{Fe} 2+)$ minerals. This colour composite was produced after data fusion data (15m) (Fig. 4) and without data fusion data (30m) (Fig. 5). 


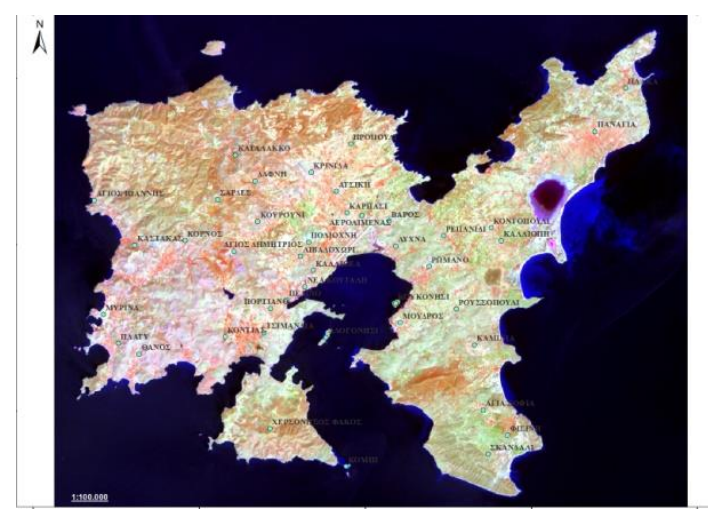

Figure 2 - colour composite image 7, 5, 3 (RGB).

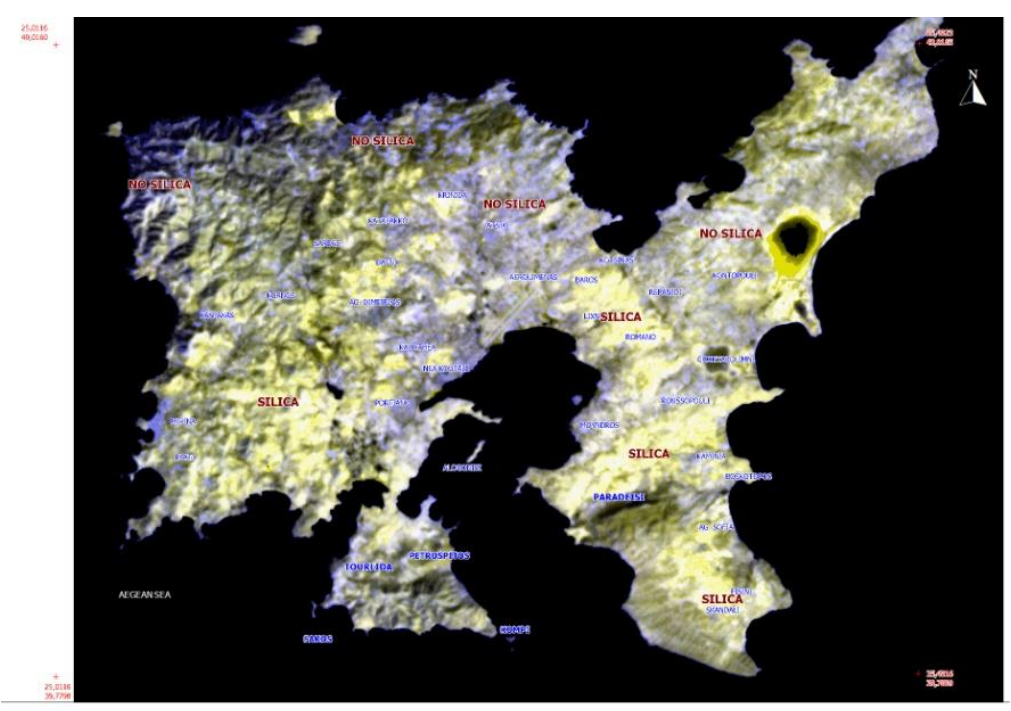

Figure 3 - Silica distribution. Silica rocks yellow colour and no silica purple (10-11-7) (RGB).

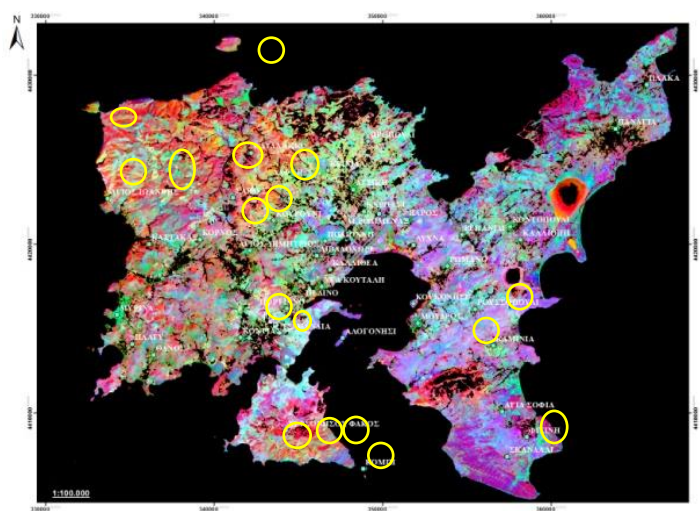

Figure 4 - composite ratio image 6/7 (clays) 4/2 (FeO) 6/5 (Ferrous) (RGB). After data fusion (15m).

The lineaments that were extracted from the panchromatic image (band 8) provided the general tectonic view of the island. 


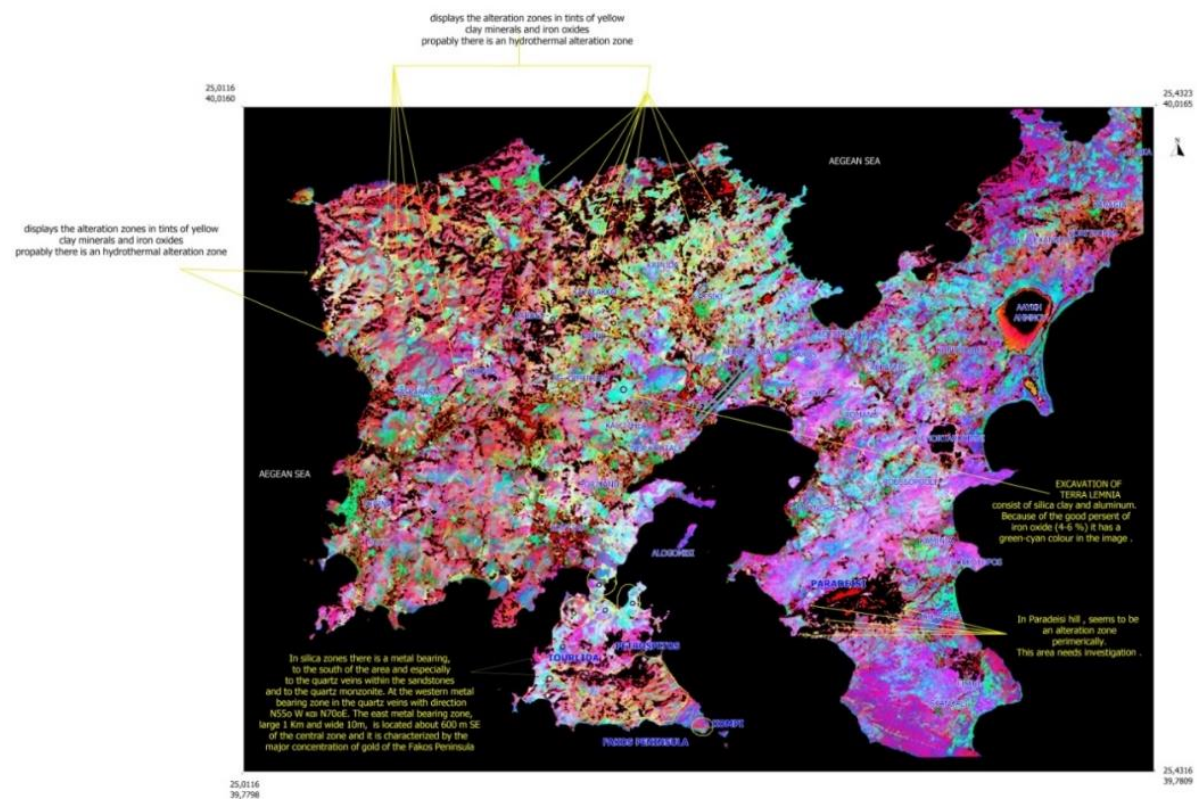

Figure 5 - composite ratio image 6/7 (clays) 4/2 (FeO) 6/5 (Ferrous) (RGB). Without data fusion. $(30 \mathrm{~m})$ the black area is the vegetation mask and the sea mask.
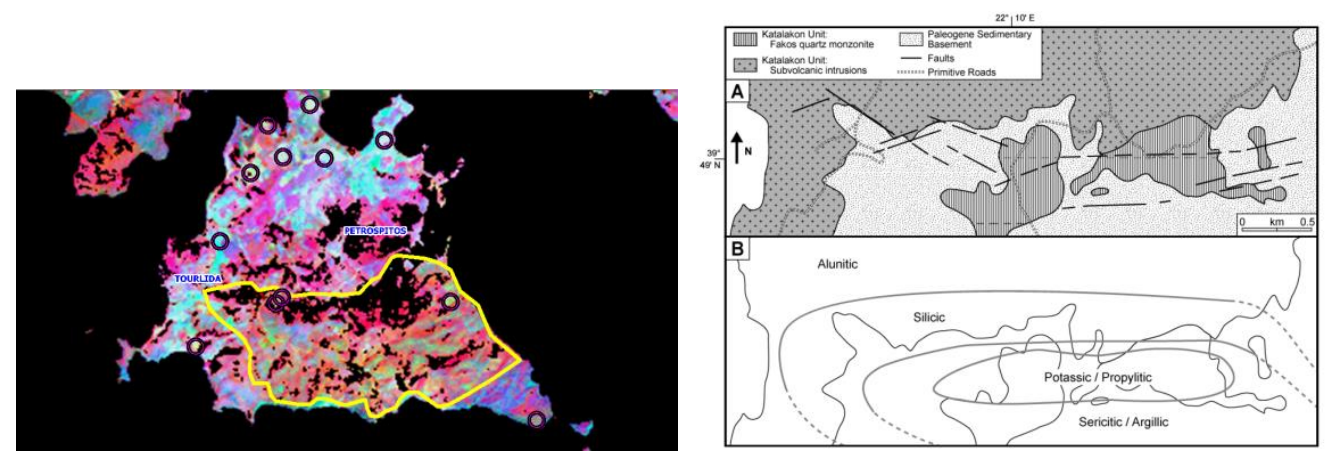

Figure 6 - Left: the main hydrothermal alteration zone in Fakos Peninsula. Right: Limits of hydrothermally alteration zones in Fakos Penisnula by Fornadel, 2010.
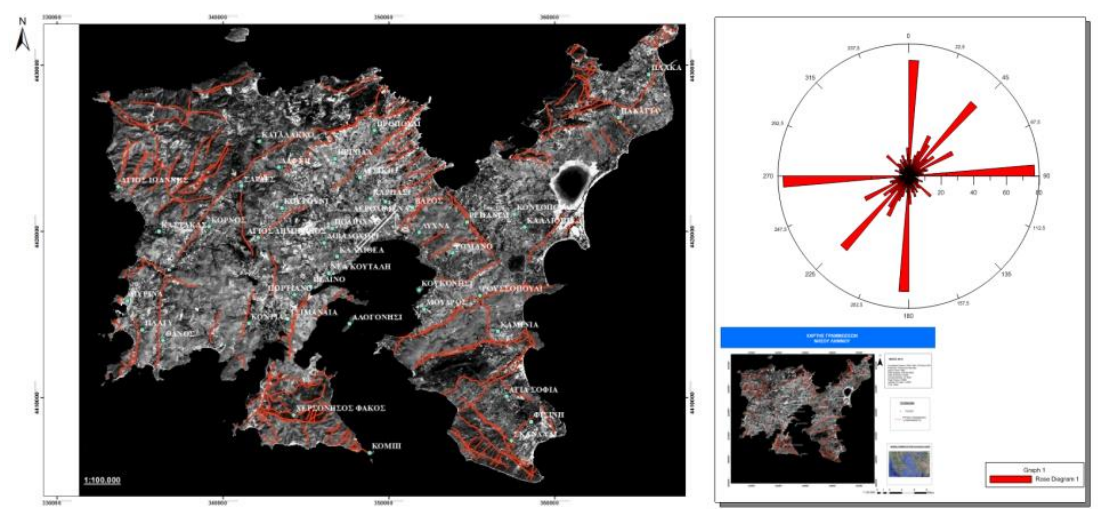

Figure 7 - Left: Lineaments issued from the panchromatic image of Landsat 8 OLI. Right: The lineament directions are shown in the rose diagram (by demo surfer 11 golden). 


\section{Results and Discussion}

The colour composite image 7, 5, 3 (RGB) can give an analysis of the landcover. The red and brownish areas correspond to vegetation, while the white colour corresponds to rocks and soil. Generally, the vegetation in the island is very low, and as it is shown in fig. 2 the vegetation extends mainly in drainage systems and hills. The colour composite image 10,11,7 (RGB) shows the spectral signature and distribution of silicate. Yellowish and yellow colours correspond to areas with silica presence and purple to areas of absence of silica as it is shown in Fig. 2. The Figures 4, 5 and 6 show the areas with hydrothermal alteration zones.

- Alteration in Fakos Cape: A zone about $16 \mathrm{~km}$ at the south of Fakos cape which separates the tints of red-yellow from tints of blue-cyan. Inside the alteration zone the tints of yellow shows the high reflectance at bands 6 and 4 and low reflectance at other bands 2, 7, 5. The different tints of yellow indicates the predominance one of the two kind of rock (iron oxides-clay minerals) (Parcharidis et al., 1998). The tints of blue-cyan perimetricaly external of the alteration zone are referring to ferrous-iron oxide (high reflectance to band 4). The geological bedrock is characterized by ploutonian rocks that have intruded in the sediments age Upper Eocene-Oligocene and present strong alteration (granites, syenites, diorites, biotite). The alteration products of trachiandesites are clays and iron oxides (serikite, chlorite, calcite, iron oxides). Also, a smaller alteration zone $(\sim 3 \mathrm{~km})$ exists at NE of Fakos cape and the geological bedrock consists of trachiandesites. Unfortunately because of the low spectral analysis of Landsat $8 \mathrm{OLI}$ it is impossible to detect and map specific rocks. Furthermore, the mask of vegetation does not allow the possibility of vegetation existence where there is a high reflectance in 5 and 6 bands. Also in that area the rocks have impregnated with iron oxides (geological map of IGME) which means high reflectance at band 4. Fornadel, 2010 has mentioned the existence of metallic minerals in the western ore zone that have been oxidized, as denoted by the abundance of iron oxides (i.e. limonite, goethite) in the vein material, and largely disseminated in the vein matrix, although locally it forms $\geq 1$ $\mathrm{cm}$ wide aggregates or infillings. The metallic minerals include pyrite, chalcopyrite, sphalerite, galena, arsenopyrite, tetrahedrite, bournonite, hessite, altaite, and native gold. These minerals can be detected with hyperspectral data. At the NE in Fakos cape there is cyan colour (width $\sim 300 \mathrm{~m}$ and length $\sim 2$ $\mathrm{km}$ ) due to the fact that there are iron oxides according to the geological map of IGME. The geological bedrock consists of silificated volcanic rocks whose initial composition has change from the influence of hydrothermal fluid which are rich to $\mathrm{SiO} 2$ through faults. There are reddish lavas because of the abidance of iron oxides. Fornadel, 2010 mentioned about a veins system which penetrates the silica alteration zone and the adjacent rocks. The veins consist of small quantities of tourmaline, barite and sericite. Ore minerals in the eastern ore zone include galena, sphalerite, arsenopyrite, and bournonite. The silica distinguishment can be confirmed at the map in fig. 3. The alunitic alteration zone, as well as the topographically higher silicic alteration zone, is crosscut by hydrothermal breccias in which alunitized rock fragments are surrounded and cemented by iron oxides. Alunite also occurs in veins, which consist of alunite, sulfur, and tridymite/cristobalite that crosscut sericitized rock in the northern part of the study area.

- Other alteration in the island: At the NW of the island near Sardes and at the west coast there are small areas with hydrothermal alteration, as well as, at the east of the island in Roussopouli near to the contact with the tuffs. Finally, parametrically of Paradeisi hill, is seemed to be an alteration zone around the vegetation (black color) and at the west Fig.5. At the geological map of IGME this area is characterized of sediments (Up. Heocene-Oligocene) and at the west there is a contact with trachiandesites. At Paradeisi hill, geological map shows impregnation of iron oxides and sulfides.

\section{Conclusion}

The aim of this study was to conduct an investigation using Landsat 8 data and remote sensing techniques to map the alteration zones in Limnos Island. The outcome of the remote sensing techniques such as colour composite and band ratios are promising in mapping lithological and altered rocks. Band 
ratio technique showed the distribution of the alteration zones. The results showed that Landsat 8 data have the potential to detect and map hydrothermal alteration zones at a regional scale.

\section{References}

Ahmed, S.O.A. and Pour, B.A., 2014. Lithological mapping and hydrothermal alteration using Landsat 8 data: a case study in ariab mining district, red sea hills, Sudan, International Journal of Basic and Applied Sciences, 199-208.

Pour, B.A. and Mazlan, H., 2014. Hydrothermal alteration mapping using Landsat-8 data, Sar Cheshmeh copper mining district, SE Iran, Journal of Taibah University for Science.

Pour, B.A. and Mazlan, H., 2011. The Earth Observing-1 (EO-1) satellite data for geological mapping, southeastern segment of the Central Iranian Volcanic Belt, Iran, International Journal of the Physical Sciences, 7638-7650, Academic Journals.

Bedini, E., 2010. Mineral mapping in the Kap Simpson complex, central East Greenland, using HyMap and ASTER remote sensing data. Geological Survey of Denmark and Greenland (GEUS), DenmarkInstitute of Geography and Geology (IGG), Advances in Space research, 60-73.

Bradley, K.E., Vassilakis, E.M., Hosa, A.L. and Weiss, B.P., 2013. Segmentation of the Hellenides recorded by Pliocene initiation of clockwise block rotation in Central Greece, Earth and Planetary Science Letters, 6-19.

Douros, K., 2008. Hyperspectral analysis of satellite images for the study of qualitative and quantitative physical parameters with the use of Doctoral paper, Thessaloniki (in greek).

Fornadel, A., 2010. Mineralogical, petrological, stable isotope, and fluid inclusion studies of the Palea Kavala reduced intrusion-related and the transitional Fakos porphyry $\mathrm{Cu}-\mathrm{Mo}$ to epithermal Au-Te ore systems, Graduate Theses and Dissertations, Paper 11798.

van Der Meer, F.D., van Der Werff, H.M.A., van Ruitenbeek, F.J.A., Hecker, C.A., Bakker, W.H., Noomen, M.F., van Der Meijde, M., Carranza, E.J.M., de Smeth, J.B. and Tsehaie, W., 2012. Multi- and hyperspectral geologic remote sensing: A review, International Journal of Applied Earth Observation and Geoinformation, 112-128.

Hajibapir, G., Lotfi M., Zarifi A.Z. and Nezafati, N., 2014. Application of Different Image Processing Techniques on Aster and ETM+ Images for Exploration of Hydrothermal Alteration Associated with Copper Mineralizationsm Mapping Kehdolan Area (Eastern Azarbaijan Province-Iran), Open Journal of Geology, 582-597.

Hunt, G.R., 1977. Spectral signatures of particulate minerals in the visible and near infrared, Geophysics, 501-513.

Kilias, S., Methods of research and evaluation of raw materials. University of Athens class of Geology and Geoenvironment, area of Economical Geology and Geochemistry (in greek).

Kolokousis, P., 2008. Development of a complete system of Hyperspectral and thermical remote sensing for the detection of coastal and submarine water springs, Doctoral Paper, Athens National Technical University of Athens (NTUA), 61-68 (in greek).

Kruse, F., Boardman, W. and Huntington, J., 2003. Final Report: Evaluation and Geologic Validation of EO-1 Hyperion (NASA Grant NCC5-495), Commonwealth Scientific \& Industrial Research Organisation (CSIRO), Division of Exploration and Mining, North Ryde, NSW, Australia.

Yu, L., Porwal, A., Holden, E.-J. and Dentith, M.C., 2011. Suppression of vegetation in multispectral remote sensing images, International Journal of Remote Sensing, 32(22), 7343-7357.

Melfos V. and Voudouri, P., 2012. Geological, Mineralogical and Geochemical Aspects for Critical and Rare Metals in Greece, Minerals, 300-317.

Griffin, M.K., Hsu, S.M., Burke, H.-H.K., Orloff, S.M. and Upham, C.A., 2005. Examples of EO-1 Hyperion Data Analysis volume 15, number 2, Lincoln Laboratory journal, 271-298.

Migiros, M., Paulopoulos, A., Parcharidis, Is., Gatsis, I. and Psomiadis, E., 2003. Remote sensing applies in Geosciences, Laboratory of Mineral Geology - class of Geological Sciences \& Atmospherical Environment Agricaltural University of Athens (AUA) (in greek).

Gül, M., Gürbüz, K. and Özgür, K., 2011. Lithology Discrimination in Foreland Basin with Landsat TM, J. Indian Soc. Remote Sens., 257-269. 
Papoulis, D., Tsolis-Katagas, P., Kalampounias, A.G. and Tsikouras, B., 2009. Progressive formation of halloysite from the hydrothermal alteration of biotite and the formation mechanisms of anatase in altered volcanic rocks from Limnos island, Northeast Aegean, Greece, Clays and Clay Minerals, 57, 566-577.

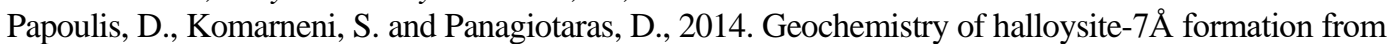
plagioclase in trachyandesite rocks from Limnos Island, Greece, Clay Minerals, 49, 75-89.

Parcharidis, I., Psomiadis, E. and Gartzos, E., 1998. Alteration zones detection in Lesvos island, through the application of Landsat 5 TM band ratio images, Mineral wealth, 112/1999.

Parcharidis, I., Psomiadis, E. and Gartzos, E., 2001. Evaluation of remote sensing methods for the detection of hydrothermal alteration zones in milos island (Greece), Bulletin of geological society of Greece, XXXiv/5, 2047-2054, Proceedings of the 9th international Congress, Athens.

Parcharidis, I., Psomiadis, E. and Tsintzouras, S., 1998. Remote sensing and raster geographic information system Techniques detecting the relation between natural vegetation and lithology - Morphology, Bulletin of geological society of Greece, xxxii/1, 297-305, Proceedings of the 8th international Congress, Patra.

Sabins, F.F., 1999. Remote sensing for mineral exploration, Ore Geology Reviews, 14, 157-183.

Al RawAshdeh, S. and Saleh et Mufeed Hamzah, B., 2006. The use of Remote Sensing Technology in geological Investigation and mineral Detection in El Azraq-Jordan, Cybergeo, European Journal of Geography [En ligne], Systèmes, Modélisation, Géostatistiques, document 358.

Sarajlic, S., 2012. Land Cover Change and Mineral Composite Assessment of Tushka Depression, in Egypt, Using Remote Sensing and GIS, Sanford Bederman Research Award, Paper 1.

Shihua Z. and Guest, B., 2014. Department of Geology, University of Calgary, Larry S. Lane, Geological Survey of Canada Calgary (2014) Analysis of Landsat ETM+ Image Enhancement enhancement for Lithological Classification Improvement in Eagle Plain Area, Northern Yukon.

Skarpelis, N., 2002. Introduction to economic geology, University of Athens class of Geology area of Economic Geology and Geochemistry, 70 pp. (in greek).

Skarpelis, N. and Voudouris, P., 1998. Epithermal gold-silver mineralization at Perama (Thrace) and Lemnos Island, Geological Society of Greece Bulletin, 32, 125-135.

Tsilavo, R. and Kusky, T.M., 2005. Structural and remote sensing studies of the southern Betsimisaraka Suture, Madagascar, Gondwana Research, 10, 186-197.

Yang, K., Huntingon, J.F., Phillips, R.N., Gemmell, J.B. and Fulton, R., 1997. Exploration and mining report $306 \mathrm{R}$ Spectral signatures of hudrothermal alteration in the volcanic rocks at Hellyer, Tasmania, Australian mineral industries research association.

Vincent R. K., DR. Beck R. A., 2005. Spectral Ratio Imaging with Hyperion Satelite Data for Geological Mapping NASA GRANT NUMBER: NCC3 1093. 